Issue 9, 2021

https://doi.org/10.23939/sisn2021.09.142

УДК 004.043

\title{
DEFINITION OF PROFESSIONAL VECTOR IN EDUCATIONAL SYSTEMS OF TRAINING FUTURE IT SPECIALISTS
}

\author{
Yurii Dubas, Natalia Kunanets \\ Lviv Polytechnic National University \\ blabla304@gmail.com, ORCID 0000-0002-9847-7661 \\ nek.lviv@gmail.com, ORCID 0000-0003-3007-2462
}

(C) Dubas Y., Kunanets N., 2021

Nowadays, the quality of vocational education directly depends on such characteristics as readiness for independent work, individualization of programs, self-improvement and self-development, the ability to acquire knowledge and use them productively in professional activities. Thus, the individualization of education plays an important role.

This article describes and analyzes the method of determining career guidance, known as the John Holland test, presents a model of its work and justifies the results. Also, the previously implemented recommendation system is mentioned and considered, which allows to form an individual educational trajectory for students of IT specialties. This system uses a sub-module for determining career guidance, which is implemented on the basis of the Dutch test. Accordingly, the use of the Dutch method in the work of the recommendation system for the formation of an individual educational trajectory will provide a more accurate and desirable result. Holland's test was also used to survey the graduating class to choose an IT profession and showed unexpected results.

Key words: professional orientation; individual educational trajectory; holland code; intersection of sets.

\section{Introduction}

Modern society dictates new requirements for man, in particular, the presence of new forms of behavior, thinking or cooperation, as well as responsibility for their actions. The role of providing these conditions is assumed by education, especially higher education, which can be considered the main driver of social and economic progress, because the highest value, like the main capital is a person who is able to seek and master new knowledge. This problem becomes especially necessary in the training of future teachers of information technology disciplines due to the increased requirements for professional competence.

In Ukraine, the quality of professional training of future specialists in the IT industry is mainly focused on the European dimension, where the defining characteristics are readiness for independent work, individualization of programs, self-improvement and self-development, ability to acquire knowledge and use them productively in professional activities. Thus, teachers of IT specialties face the task not only to form in students a certain level of professional knowledge and skills, but also to develop in them the ability to solve problems, to independence in educational work, teamwork, information retrieval, its processing and application.

\section{Analysis of recent research and publications.}

The problem of individualization of the educational process is a widely discussed topic in recent years. Various aspects of this process are considered in numerous studies, in particular, E. Alexandrova considered 
the individual educational trajectory as a way to realize the personal potential of students. In addition, this concept refers to the program of formation and development of life, in particular personal, for a certain period of time [1, p. 75].

Another researcher, I. Kankovsky, understands this concept as a movement chosen by a student in accordance with an individual educational route to achieve a certain level of professional competence, defined by the standard of education, in terms of personal responsibility and desire. At the same time, the individual educational route can be presented in the form of an individual program of student professional competence formation taking into account one's own interests, educational opportunities, psychological characteristics, etc. [2, p. 63].

According to S. Kliminska, the individual pace and volume of educational work intensify the cognitive activity of the student, improve his abstract and analytical activities, motivate active creative work. This contributes not only to the implementation of individual educational trajectory, but also allows you to form a professional personality of the future specialist [3].

Thus, we can conclude that the individual learning trajectory is a personal path of personal development of the potential of the student. This path is formed taking into account the abilities, interests, needs, motivation, capabilities and experience of the applicant, and is based on his chosen types, forms and pace of education, educational programs, disciplines and their level of complexity, methods and teaching aids. The individual educational trajectory is also determined through the individual curriculum.

Accordingly, the implementation of an individual educational trajectory requires a tool that will take into account the personal characteristics of the applicant, his interests, needs or motivations, as well as provide further advice on choosing a suitable educational institution.

Much research on learning trajectories has been conducted abroad. A large number of studies have described that students' decisions on how they construct their educational trajectories are deeply embedded and subject to their context. This may refer to their environment, including their peers, family context, context of growing up and neighbourhood. In addition, not only may individual experiences matter, but also the organizational structures of the educational institution in which students are embedded (meso-level), or further, the regional or national structure of the educational system (macro-level) [4].

Several studies encompassed some meso-theoretical concepts, i.e. how the organizational context of the educational institutions influences how students proceed through individual education. For example, Meggiolaro et al. [5] argued that larger educational institutions provide more and better services to students. Thus, this is beneficial for students' persistence. They also refer to the well-known finding that more selective programmes and institutions also have higher persistence rates.

In addition to the organizational context of the educational institutions, the structure of the higher educational system as well as that of the education system in general shape students' trajectories. For example, the openness of an educational system affects how large the share of a cohort is that can access higher education. Fees and financial aid systems as well as the selectivity of higher education, alternative routes and the existence of strong alternatives to higher education matter [4].

The aim of the paper is to analyze the functionality of Holland test and its implementation within the recommendation system for the formation of an individual educational trajectory.

\section{Problem overview}

The best tool for constructing the individual educational trajectory is a recommendation system in favor of entrants who dream of studying in the specialties of the IT industry. The project of this system provides for the development of four modules that will perform all the necessary processes:

- Module for determining professional orientation;

- Module for finding an educational institution;

- Module for defining disciplines;

- Module for formation of individual educational trajectory.

All modules of the recommendation system and their interaction are shown in Fig. 1. 


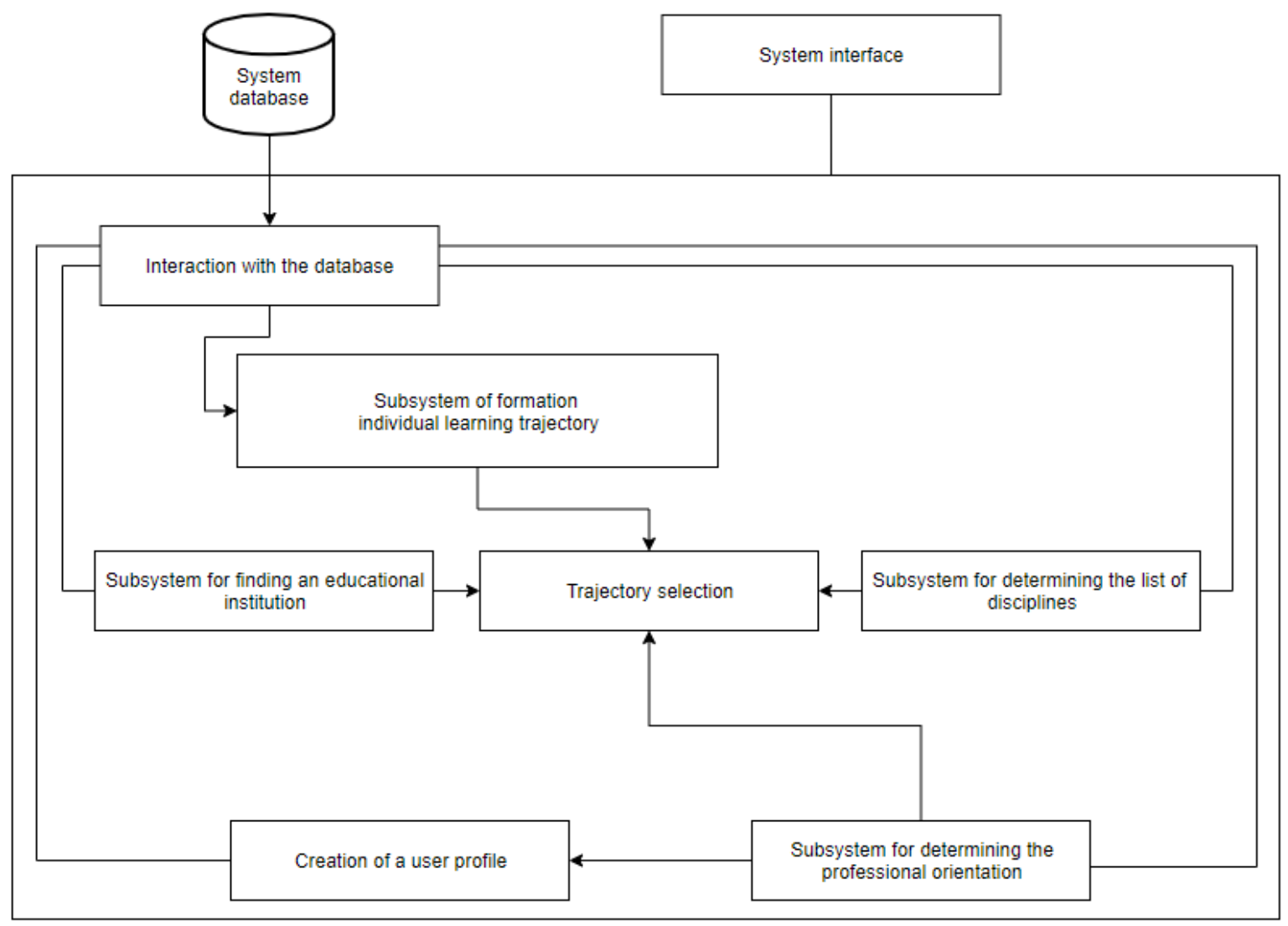

Fig. 1. Structural model of the recommendation system

The first module is not mandatory for the recommendation system, but will provide much more accurate results, given the professional orientation of students. This is the module we will examine and analyze.

In general, professional orientation is a measure aimed at establishing the abilities and capabilities of the entrants in order to offer them to choose one of the most characteristic professions. At the same time, professional orientation is understood as a scientific discipline that helps a person choose his future profession, taking into account all his abilities, needs and desires [6].

Historically, professional orientation was considered from the standpoint of counseling the applicant in professional self-determination for life.Subsequently, it turned out that such a technique does not give the desired results. This was often due to the adherence to the advice and requirements of the career counselor and different views, individual characteristics and skills of the applicant. It often happened that applicant later had a reluctance to continue the profession, which was chosen in accordance with specific requirements.

Thus, the procedure of counseling support for career guidance has established its relevance not only as a one-time action, but throughout the whole life.

In particular, the peculiarities of professional orientation were studied by the American psychologist John Lewis Holland, which let him develop a model of career development, called Holland Occupational Themes, commonly known as the Holland Codes.

Holland argued that people work best in a work environment that suits their preferences. People and work environments can be selected for the best fit. Most people are a combination of two or three "areas of Holland interest". These two or three areas are considered Holland Code. [7]

Holland Codes - one of the most popular models today, used to determine professional orientation. Holland argued that "the choice of a vocation is an expression of personality" [7]. Thus, there are six personality types in the model and most people fit into these several categories. This model is shown in Fig. 2.

Holland initially described his six types as "motor, intellectual, aesthetic, supportive, persuasive, and relevant". He later developed and changed them to: "Realistic (performers), research (thinkers), artistic (creators), social (assistants), enterprising (beliefs) and conventional (organizers)". 


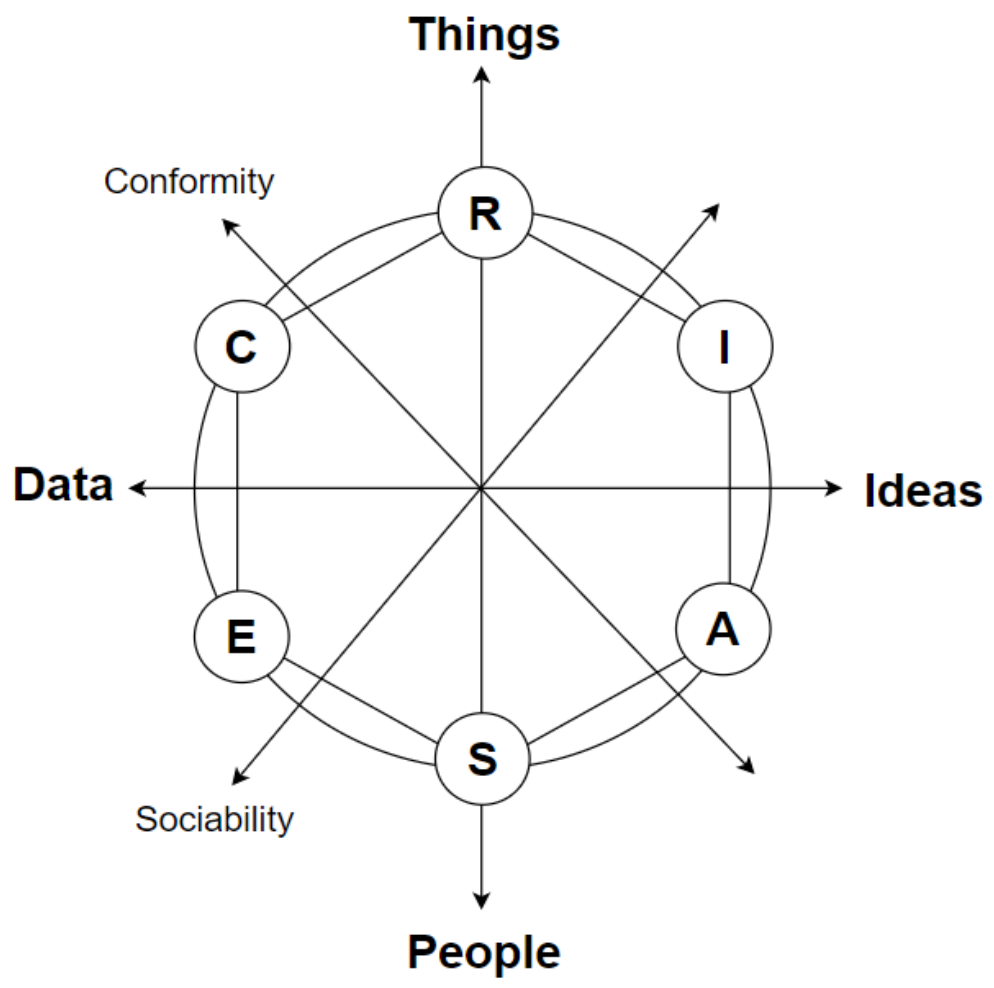

Fig. 2. Holland Code model

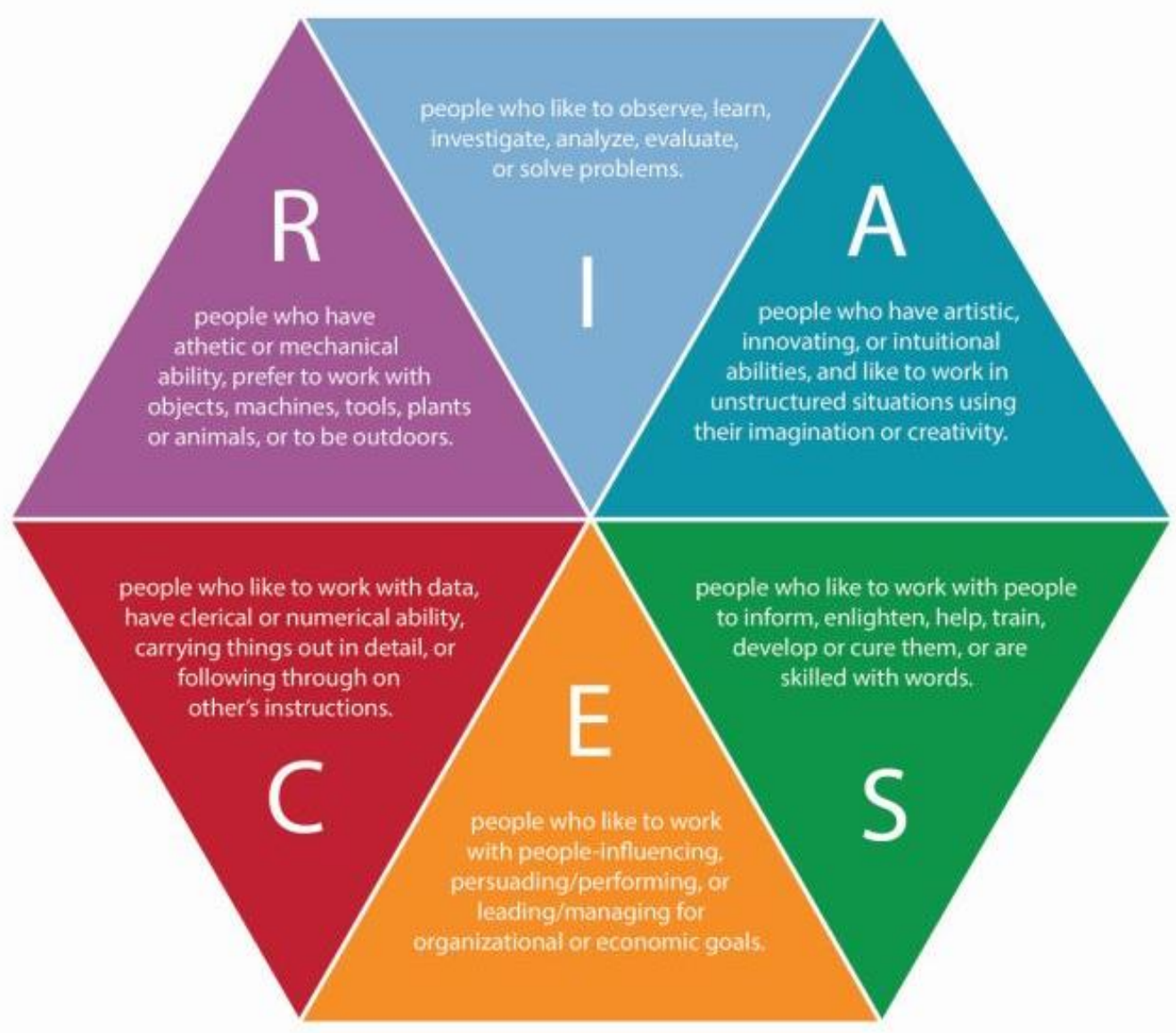

Fig. 3. Six personality types 
These personality types are shown in Fig. 3.

- Realistic (R): practical, physical, concrete, practical, machine and tool-oriented;

- Research (I): analytical, intellectual, scientific, research, thinker;

- Social (S): cooperation, support, assistance, education, training;

- Conventional (C): focus on details, organizing, stationery;

- Entrepreneurial (E): competitive environment, leadership, beliefs, status;

- Artistic (A): creative, original, independent, chaotic, inventive, media, graphics and text.

Based on Holland Codes, a test was created, which would determine a person's professional aptitude. The test itself is named after the author (Holland test) and is as follows:

The participant is asked to choose one from each pair of professions. There are forty-two of these pairs. The choice should not be made in terms of the best financial security, but as the most desirable, the best. After selecting all professions and processing the data according to the key, the participant receives a result indicating the extent to which it reveals one of the six personality types.

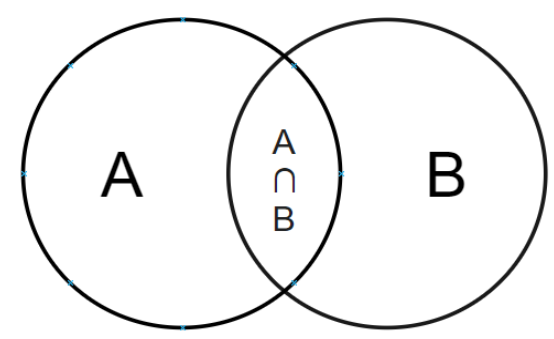

Fig. 4. The intersection of sets is user's Holland Code

The key to the test is essentially based on sets representing each of the six personality types and the participant himself. If the set of participants (A) intersects the set of personality (B), the user's Holland Code is formed, which detects the predisposition of $\mathrm{A}$ to $\mathrm{B}$ and is denoted by $\mathrm{A} \cap \mathrm{B}$. This connection is described in Fig. 4.

It is also worth noting that there may be several intersections, as the tendency may be not only to one type of personality, but also to others. Accordingly, the user's Holland Code can be represented by the abbreviations of individuals, RIASEC, so, the intersection of sets of research, artistic and social personality types will result in the following Holland Code: IAS

The Holland test was implemented as a module for determining professional orientation in the recommendation system for the formation of an individual educational trajectory. The algorithm of this test within the recommendation system is shown in Fig. 5.

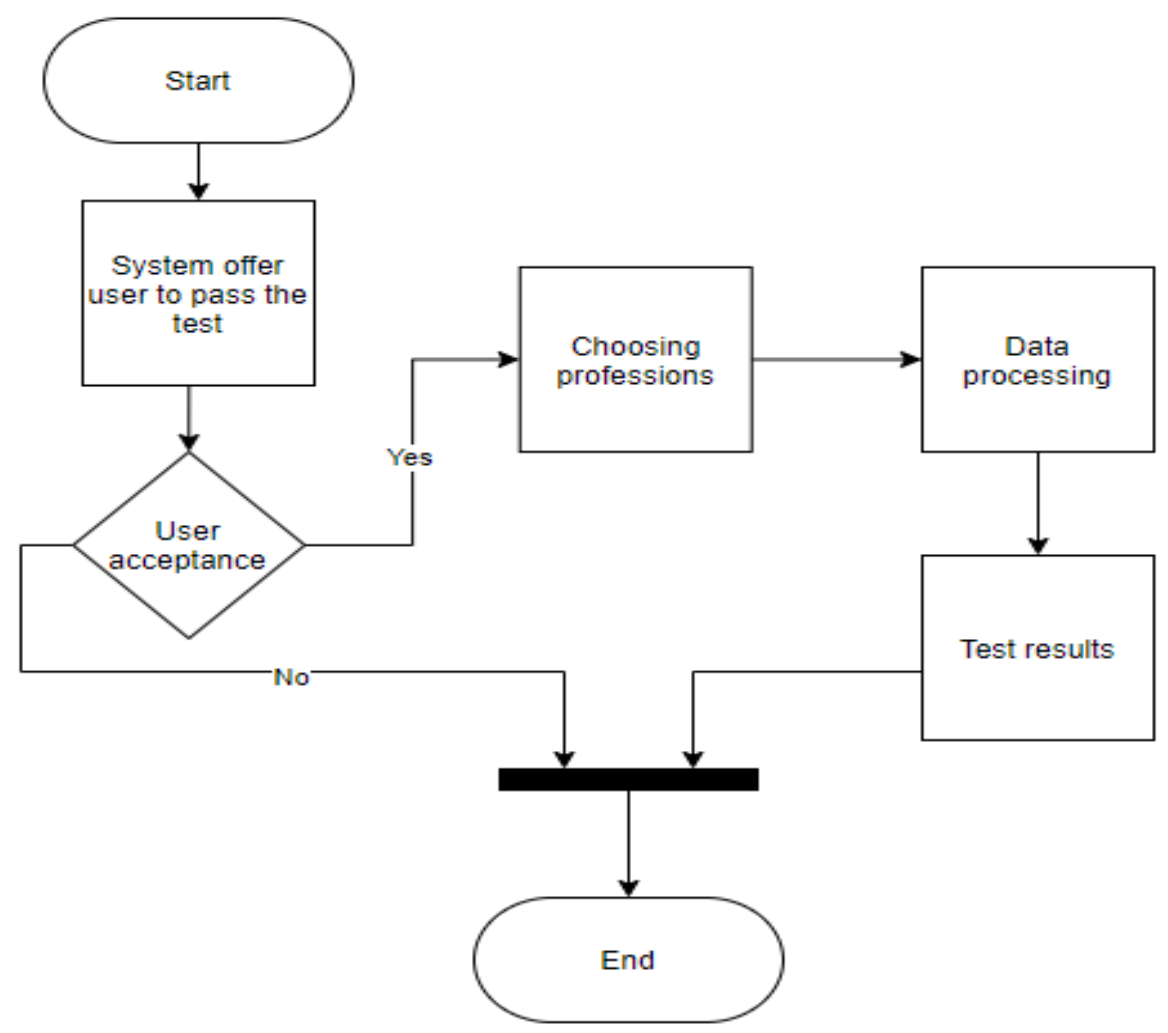

Fig. 5. Algorithm of module operation for determination of professional orientation 
It consists of the following steps:

Step 1: The system offers the user to take a Holland test to determine their professional orientation. The user can agree or refuse to take the test. The test is not required to form an individual educational trajectory, but will provide more accurate results. In case of refusal, the system ignores the entire module to determine professional orientation and continues to work according to the general algorithm of the program, which is shown in Fig. 6 and Fig. 7.
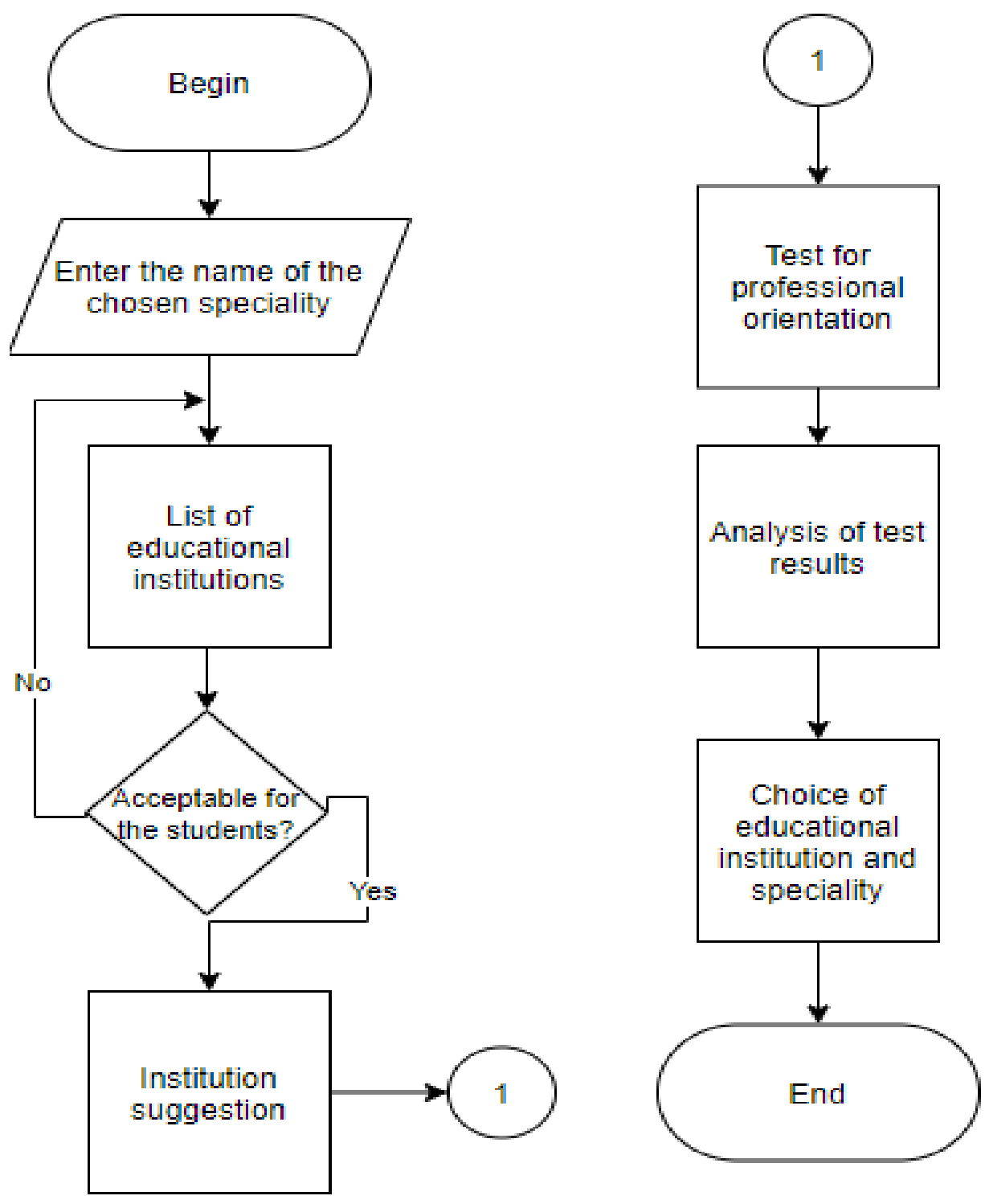

Fig. 6. Recommendation system algorithm

Step 2. If the user agrees to take the test, the system runs the Holland test, where the user is asked to choose one profession from forty-two pairs.

Step 3. The user chooses the most desirable profession for each couple. The system records each user's choice and enters this information into a database.

Step 4. As soon as the user completes the choice of professions, the system processes the data and displays the result. 


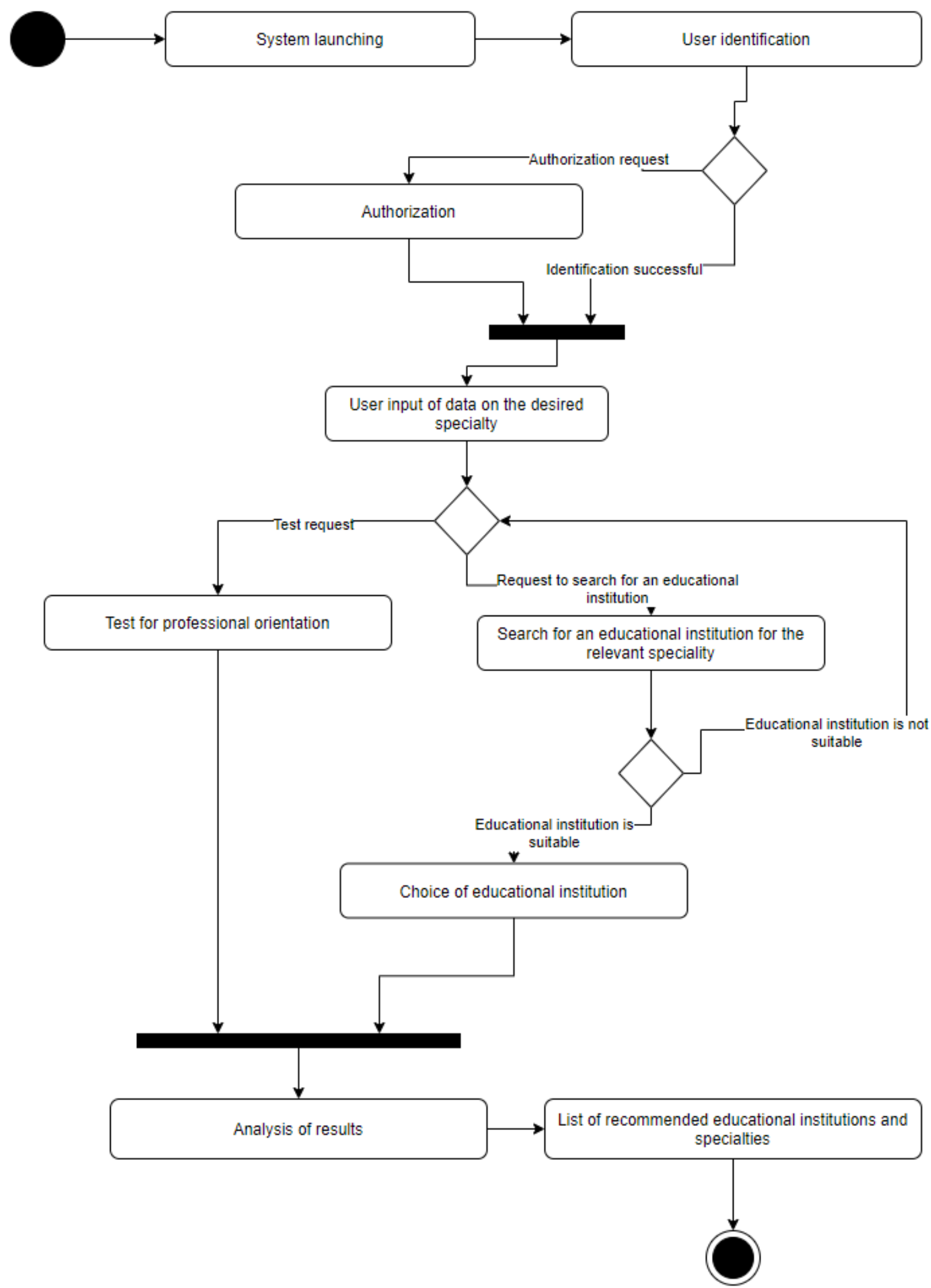

Fig. 7. Scheme of functioning of the recommendation system

Also, with the help of the Holland test, a survey was conducted among high school graduates. The survey was conducted in order to identify the propensity for information technology disciplines. The results of the survey are shown in Fig. 8. 
The results of the questionnaire let us conclude that despite the future plans of graduates and their wishes, only about $10 \%$ of those who were questioned received IC (Investigative and Conventional) personality type, which means a tendency to information technology disciplines.

Thus, it confirmed that professional orientation may be an important factor in shaping an individual educational trajectory.

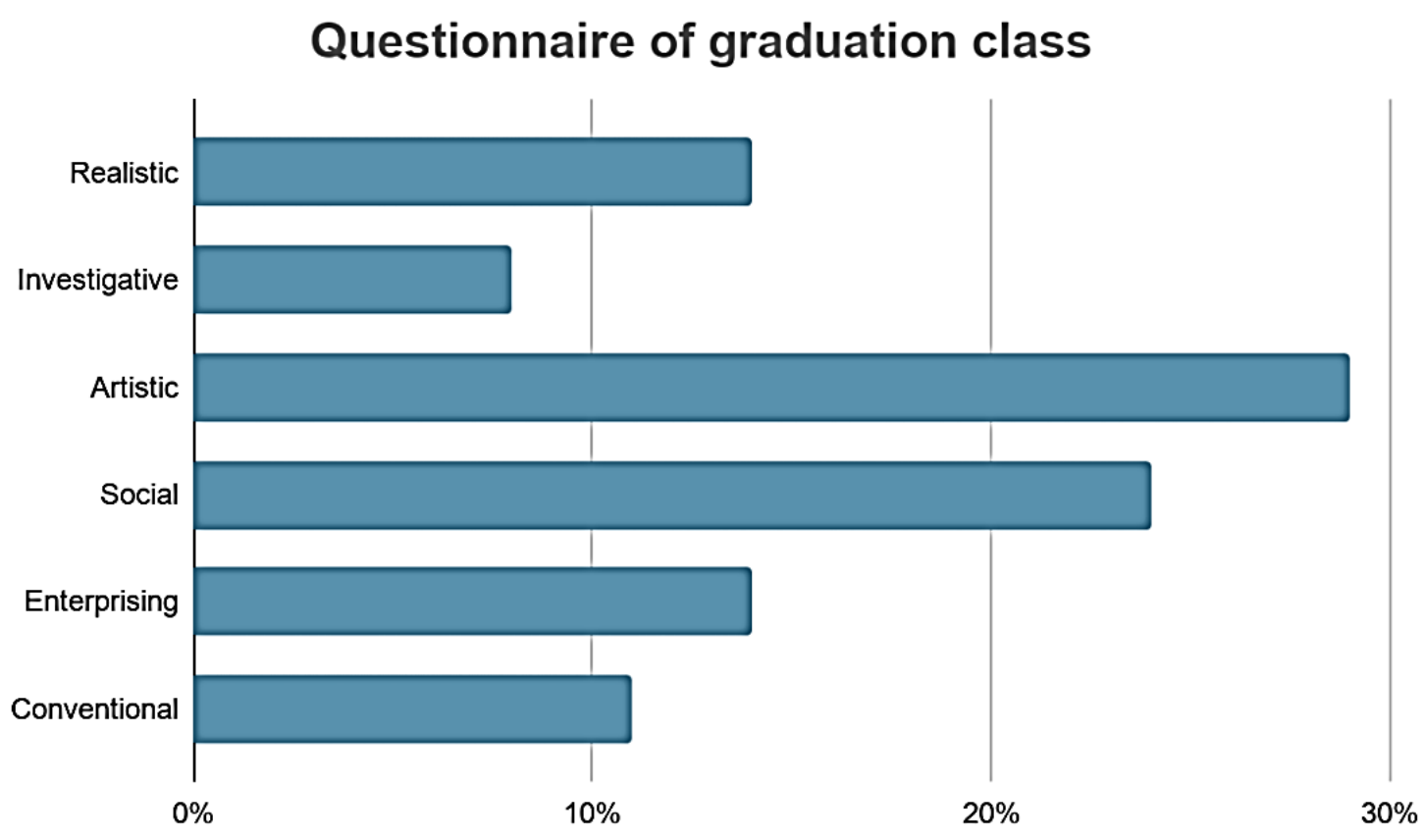

Fig. 8. Questionnaire of graduation class

\section{Conclusions}

The study showed that the module for determining professional orientation is an important element of the recommendation system for the formation of individual educational trajectories of students of IT specialties and requires further implementation. The Holland test, which was taken as a basis for the module, is not absolute, but provides high efficiency along with ease of implementation. Due to the high number of online tests that use the Holland Codes, it is advisable to use online technologies to implement both the module and the recommendation system as a whole.

\section{Список літератури}

1. Александрова, Є. А. (2008). Педагогічна підтримка старшокласників у процесі розробки та реалізації індивідуальних освітніх траєкторій. Известия Саратовского университета. Новая серия. Серия "Акмеология образования, Психология развития", 1-2, 74-78.

2. Каньковський, I. Є. (2013). Індивідуальні освітні траєкторії як необхідність сучасного процесу професійної підготовки фахівця. Професійна освіта: проблеми і перспективи, 4, 62-65.

3. Клімінська, С. Л. (2014). Індивідуальна освітня траєкторія як спосіб підвищення ефективності викладання іноземних мов. Науковедение, 4 (23). URL: https://naukovedenie.ru/PDF/ 34PVN414.pdf.

4. Траєкторії студентів через вищу освіту: огляд кількісних досліджень (2019). URL: https://link.springer.com/article/10.1007/s10734-019-00458-5

5. Meggiolaro, S., Giraldo, A., \& Clerici, R. (2017). Багаторівнева модель конкуруючих ризиків для аналізу кар'єри студентів університетів в Італії. Дослідження вищої освіти, 42 (7), 1259-1274.

6. Професійна орієнтація, https://uk.wikipedia.org/wiki/\%D0\%9F\%D1\%80\%D0\%BE\%D1\%84\%D0\%B5\%D1\%81\%D1\%96\%D0\%B9\% D0\% BD\% D0\% B0_\% D0\% BE\% D1\% 80\% D1\% 96\% D1\% 94\% D0\% BD\% D1\% 82\% D0\% B0\% D1\% 86\% D1\% 96\% D1\% 8F

7. Холланд, Джон Л. (1973). Вибір професії: теорія кар'єри. Прентис Холл. 


\title{
References
}

1. Aleksandrova, Ye. A. (2008). Pedagogical support of senior pupils in the process of development and realization of individual educational trajectories. Izvestiya Saratovskogo universiteta. Novaya seriya. Seriya Akmeologiya obrazovaniya. Psikhologiya razvitiya, 1-2, 74-78.

2. Kan'kovs'kyi, I. Ye. (2013). Individual educational trajectories as a necessity of a modern process of professional training of a specialist. Profesiina osvita: problemy i perspektyvy, 4, 62-65.

3. Kliminskaya, S. L. (2014). Individual educational trajectory as a way to improve the effectiveness of teaching foreign languages. Naukovedenie, 4(23). Retrieved from: https://naukovedenie.ru/PDF/ 34PVN414.pdf.

4. Students' trajectories through higher education: a review of quantitative research (2019). Retrieved from: https://link.springer.com/article/10.1007/s10734-019-00458-5

5. Meggiolaro, S., Giraldo, A., \& Clerici, R. (2017). A multilevel competing risks model for analysis of university students' careers in Italy. Studies in Higher Education, 42(7), 1259-1274.

6. Professional orientation, Retrieved from: https://uk.wikipedia.org/wiki/\%D0\%9F\%D1\%80\%D0\%BE\%D1\%84\%D0\%B5\%D1\%81\%D1\%96\%D0\%B9\%D0\%B D\%D0\%B0_\%D0\%BE\%D1\%80\%D1\%96\%D1\%94\%D0\%BD\%D1\%82\%D0\%B0\%D1\%86\%D1\%96\%D1\%8F

7. Holland, John L. (1973). Making vocational choices: A theory of careers. Prentice Hall.

\section{ВИЗНАЧЕННЯ ПРОФЕСІЙНОГО ВЕКТОРА В ОСВІТНІХ СИСТЕМАХ ПІДГОТОВКИ МАЙБУТНІХ ІТ-ФАХІВЦІВ}

\author{
Юрій Дубас, Наталія Кунанець \\ Національний університет “Львівська політехніка” \\ blabla304@gmail.com, ORCID 0000-0002-9847-7661 \\ nek.1viv@gmail.com, ORCID 0000-0003-3007-2462
}

(c) Дубас Ю., Кунанець Н., 2021

У наш час якість професійної освіти прямо залежить від таких характеристик, як готовність до самостійної роботи, індивідуалізація програм, самовдосконалення та саморозвиток, здатність здобувати знання та продуктивно використовувати їх у професійній діяльності. Тому важливу роль відіграс індивідуалізація освіти.

У статті описано та проаналізовано метод визначення професійної оріснтації, відомий як тест Джона Холланда, наведено модель його роботи та обгрунтовано отримання результатів. Також розглянуто попередньо реалізовану рекомендаційну систему, що дає змогу формувати індивідуальну освітню траєкторію для студентів IT-спеціальностей. Така система використовує підмодуль визначення професійної орієнтації, реалізований на основі тесту Холланда. Відповідно, використання методу Холланда у роботі рекомендаційної системи для формування індивідуальної освітньої траєкторії дасть можливість отримати точніший та бажаний результат. Тест Холланда також використано для опитування учнів випускного класу на предмет вибору ІТ професії. Він показав неочікувані результати.

Ключові слова: професійна орієнтація; індивідуальна освітня траскторія; код Холланда; перетин множин. 